\title{
UTILIZATION OF THE INVASIVE PLANT IMPATIENS PARVIFLORA DC. BY THE SNAIL COLUMELLA EDENTULA DRAPARNAUD IN OAK-HORNBEAM FORESTS
}

\author{
RENATA PisKorZ ${ }^{1}$, MARIA URBAŃSKA ${ }^{2}$ \\ ${ }^{1}$ Department of Botany, Agriculture University \\ e-mail: reniapis@au.poznan.pl \\ 2 Department of Zoology, Agriculture University \\ Wojska Polskiego 71c, 60-625 Poznań, Poland
}

(Received: February 13, 2006. Accepted: November 22, 2006)

\begin{abstract}
This study investigated the extend to which the snail Columella edentula is more strongly associated with the small balsam Impatiens parviflora than with other plants in the herb layer of an oak-hornbeam forest, and to interpret the character of the interaction Impatiens parviflora-Columella edentula.

Numbers of $C$. edentula and rates of colonization were compared on various plant species under natural and laboratory conditions. Seasonal variation in snail abundance on I. parviflora was observed on permanent plots. The leaf injuries caused by $C$. edentula were localized in respect of the morphological and anatomical structure of leaves.

The results show that I. parviflora is one of the plant species of the herb layer that are most abundantly colonized by this snail in oak-hornbeam forest. Snail finds a plant particularly suitable as a place for resting. The most favoured attachment site is on the underside of the leaf, along the midrib, which provides the highest and relatively stable humidity, as well as protection from direct sunlight and predators. I. parviflora is also a food for the snails, but they do not eat these fragments of leaves where calcium carbonate is accumulated.
\end{abstract}

KEY WORDS: Impatiens parviflora, Columella edentula, interaction.

\section{INTRODUCTION}

Gastropod distribution and abundance are affected by a number of biotic and abiotic factors, which have been discussed by many authors (Wäreborn 1970, 1982; Vašátko 1973; Solem 1974; Shikov 1979; Baidashnikov 1992; Ondina et al. 1998). Plants often provide suitable microhabitats for snails and some snail species, especially herbivorus, are associated with particular plants (Cain and Currey 1967; Chatfield 1972, 1976; Pallant 1972; Nicorti 1980; Speiser and Rowell-Rahier 1991; Iglesias and Castillejo 1999).

Nevertheless, most information on the issue, is derived from accidental malacological or floristic observations; published data on snail-plant association are scanty.

Earlier observations on Impatiens parviflora, in forests of the Wielkopolska National Park (western Poland), suggest that Columella edentula might prefer this alien species to native plants (Piskorz, 2004). This prompted the present study, which was aimed at explaining this apparent preference.

\section{MATERIAL}

Columella edentula (Draparnaud) is a pulmonate Stylommatophoran snail (Falkner et al. 2001). Its distribution range includes most of Europe, except its northernmost (Island, Finland) and southernmost fringes (to the Alps), the Caucasus, Central Asia (Ložek 1964; Shileyko 1984 after Pokryszko 1990) and some parts of North America (Pokryszko 1990). In Poland it is common in a wide range of habitats: woodlands, wetlands, and meadows. It is not associated with any specific substrate type and a rather high humidity seems to be the decisive factor. In summer it is found mainly on herbs, whereas in spring and autumn it stays in the leaf litter and the surface layer of the soil. To date it has been recorded feeding on Mercurialis perennis, Asarum europaeum, Glechoma hederacea, Circaea lutetiana, Cirsium oleraceum, Petasites sp. and umbellifers (Pokryszko 1990; Pilāte 2001).

The small balsam (Impatiens parviflora DC., Balsaminaceae DC.) derives from Siberia, Mongolia, Turkestan, Dungaria, as well as the Altai and Pamir Mountains (Krawiecowa 1951; Meusel et al. 1978), so the ranges of both species overlap. 
After its introduction to botanical gardens in Geneva and Dresden, it has become naturalized and started its uncontrolled expansion in Europe. Within the present borders of Poland, it was first noted in 1850 (Krawiecowa 1951) near the Baltic port of Danzig (now Gdańsk). In the Wielkopolska National Park in western Poland it appeared in the 1960s. Now the plant is regarded as one of the most expansive species in Europe, not only because of the high rate of colonization of new areas but also because of its biocoenotic success: it enters natural phytocoenoses, forms new combinations of species and its own phytocoenoses, starts new interspecific relations with organisms first encountered in the secondary distribution range, e.g. the aphid Aphis fabae, or with species that also derive from Asia, e.g. the aphid Impatientinum asiaticum and the rust Puccinia komarovii (Stacherska 1972; Trepl 1984; Eliáš 1989, 2001; Orczewska and Chmura 2002). The published literature, however, provides no information on relations between I. parviflora and gastropods.

\section{METHODS}

\section{Field work}

Field observations were carried out in an oak-hornbeam forest (Galio-sylvatici Carpinetum) in the Wielkopolska National Park, between July and August 2001, in three experimental plots (K, L, and $\mathrm{M} ; 1 \times 1 \mathrm{~m}$ each). Plot $\mathrm{M}$ was divided into four subplots of $0.25 \mathrm{~m}^{2}$. Plots $\mathrm{K}$ and $\mathrm{M}$ were situated in places shaded by the canopy, while plot L was located in a small gap. In July and August, lists of herbs and their degree of cover were recorded for each plot. From 10 July till 22 August, at interval of a few days, all individuals of $C$. edentula were counted on all plants growing on each plot, for each plant species separately. On plots $\mathrm{K}$ and $\mathrm{L}$, snails were left on plants. On plot $\mathrm{M}$, the rates of colonization of various plant species by $C$. edentula were assessed in the following way. On two subplots of plot $\mathrm{M}$, all counted snails were removed from plants and placed on the ground. On the other two subplots, snails were left on plants. On the next count, snails were removed from plants on subplots where they had been previously allowed to stay on plants, and vice versa. On the days of snail counting, information on weather conditions (rain in particular) was recorded.

On all plots, while counting C. edentula on I. parviflora, location of the snail on the plant was recorded in 7 categories: 1) upper surface of the leaf: $a-$ along the midrib, $b-$ along lateral veins, $\mathrm{c}$ - other fragments of the leaf; 2) lower surface of the leaf: $\mathrm{a}$ - along the midrib, $\mathrm{b}$ - along lateral veins, $\mathrm{c}$ - other fragments of the leaf; 3 ) petiole or stem.

\section{Laboratory experiments}

In order to verify the results obtained in the field, the rate of colonisation was assessed under controlled laboratory conditions $(\mathrm{H})$. Plastic boxes $(20 \times 15 \times 20 \mathrm{~cm})$, were set up, each having its base penetrated four test tubes attached near the corners (Fig. 1). The tubes were filled with water. Fresh specimens of I. parviflora were put in two tubes, while specimens of another plant species were put in the other two tubes. The degree of cover by each species was about $35 \%$. The boxes were kept at room temperature under natural illumination. In each box, 50 individuals of
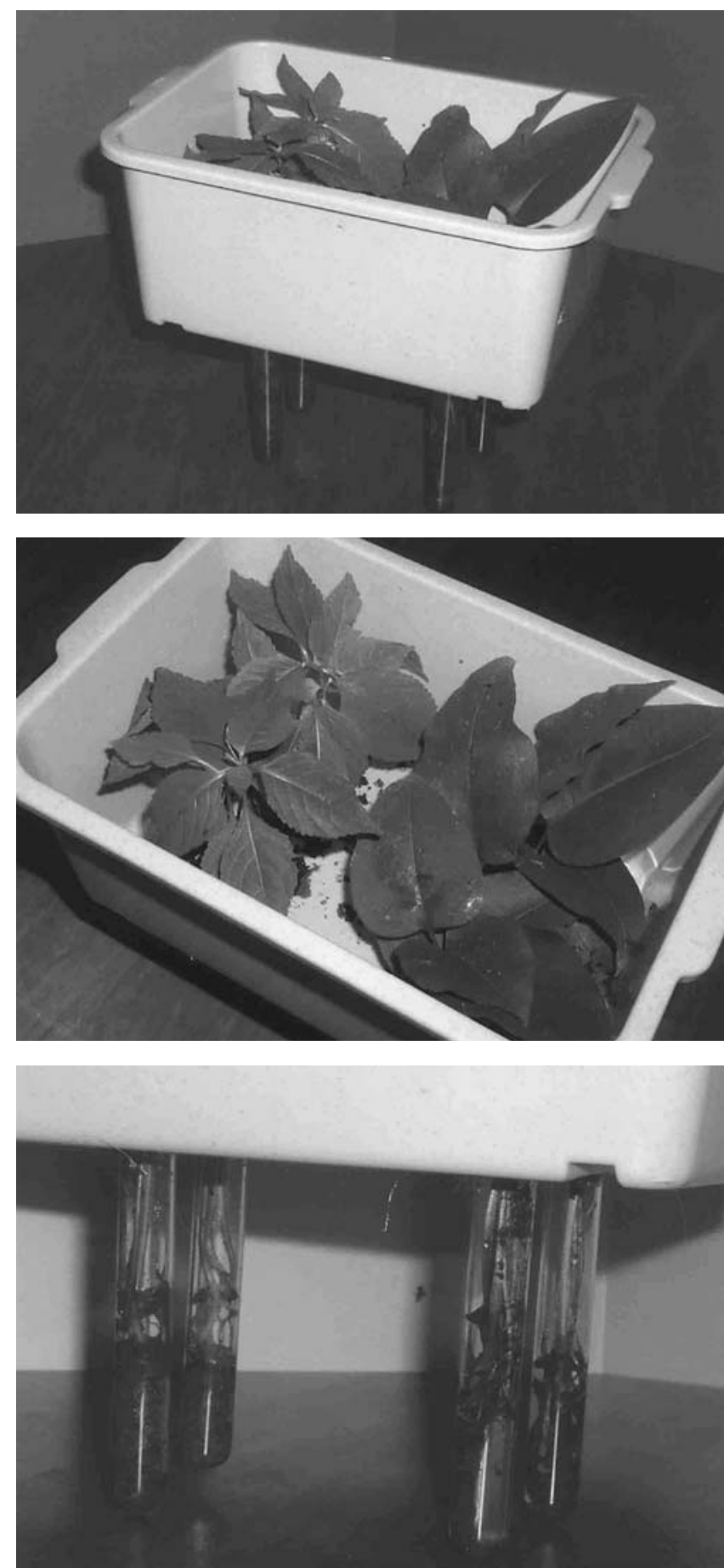

Fig. 1. Experiment design. For details see text.

C. edentula were placed, and over the next five days we recorded their numbers on each plant species. In this way, colonization of $I$. parviflora and 9 other plant species was compared.

\section{Analysis}

The results from plots $\mathrm{K}, \mathrm{L}$ and the laboratory $(\mathrm{H})$ were averaged over time and next normalized according to the following formula:

$$
N_{i}=\frac{n_{i}}{p_{i} \sum_{j} n_{j}}
$$

where $N_{i}=$ normalized number of snails on the $i^{\text {th }}$ plant species; $n_{i}=$ number of snails on the $i^{\text {th }}$ plant species; $n_{j}=$ 
number of snails on the $j^{\text {th }}$ plant species; $j=$ total number of plant species found on the plot; $p_{i}=$ degree of cover by the $i^{\text {th }}$ plant species. Due to the normalization, the results for various plant species were independent of differences in their degree of cover on the experimental plots and in the boxes. This enabled pair-wise comparisons within and between the plots, as well as between the results of field and laboratory experiments. The significance of differences was verified with Student's t-test.

\section{Feeding observations}

During field and laboratory work traces of snail feeding on leaves of I. parviflora were detected with the naked eye. It was noticed that some parts of the leaves were never damaged by snails. Microscopic sections (ca. $5 \times 5 \mathrm{~mm}$ ) of these leaf fragments, bleached with chloral hydrate (Braune et al. 1975) and embedded in gelatine with glycerine (Filutowicz and Kużdowicz 1951), were observed and photographed under a light microscope.

\section{RESULTS}

\section{Field and laboratory investigations}

The list and the cover of plants from the herb layer on permanent plots are presented in Table 1. C. edentula was present not only on I. parviflora but also on other plants, except Tilia cordata. The normalized number of individuals of $C$. edentula on I. parviflora $\left(N_{0}\right.$, taking into account
TABLE 1. Floristic lists for permanent plots K, L, and M.

\begin{tabular}{lccc}
\hline & K & L & M \\
\hline Cover of the herb layer [\%] & 59 & 73 & 80 \\
\hline Impatiens parviflora & 20 & 30 & 38 \\
Galeobdolon luteum & 25 & 25 & 20 \\
Pulmonaria obscura &. &. & 13 \\
Ulmus laevis &. & 8 & $\cdot$ \\
Carpinus betulus & 0.5 & 6 & 0.5 \\
Aegopodium podagraria & 4 & 1 & 1 \\
Oxalis acetosella & 5 &. & 5 \\
Milium effusum & 2.5 & 1 & 0.7 \\
Viola riviniana & 1 & 0.5 & 1.5 \\
Adoxa moschatellina & 0.1 &. & $\cdot$ \\
Moehringia trinervia & 0.5 & 1 & $\cdot$ \\
Tilia cordata & $\cdot$ & 0.1 & $\cdot$ \\
\hline
\end{tabular}

the degree of cover by this plant), was significantly higher than $N$ values for most other species found in the herb layer: for 7 of 8 accompanying species on plot $\mathrm{K}$ and for 6 of 8 species on plot L. Thus, under conditions of moderate shading (plot $\mathrm{K}$ ), individuals of $C$. edentula were equally frequent on I. parviflora and Adoxa moschatelina, while in the gap (plot L) the snail preferred three species: I. parviflora, Viola riviniana, and Aegopodium podagraria (Table 2). The laboratory experiment with 9 selected plant species compared with I. parviflora, showed that the $N$ value for Viola riviniana was higher than $N_{0}$, for Ulmus laevis it was

TABLE 2. Colonization $\left(N_{i}\right)$ of selected plant species of the herb layer of oak-hornbeam forest by Columella edentula. K - plot under the canopy of the forest stand; L - plot in the gap; below the plant name, the normalized number of $C$. edentula is given; $\times$ - significant $(\alpha=0.05)$ differences in colonization rate.

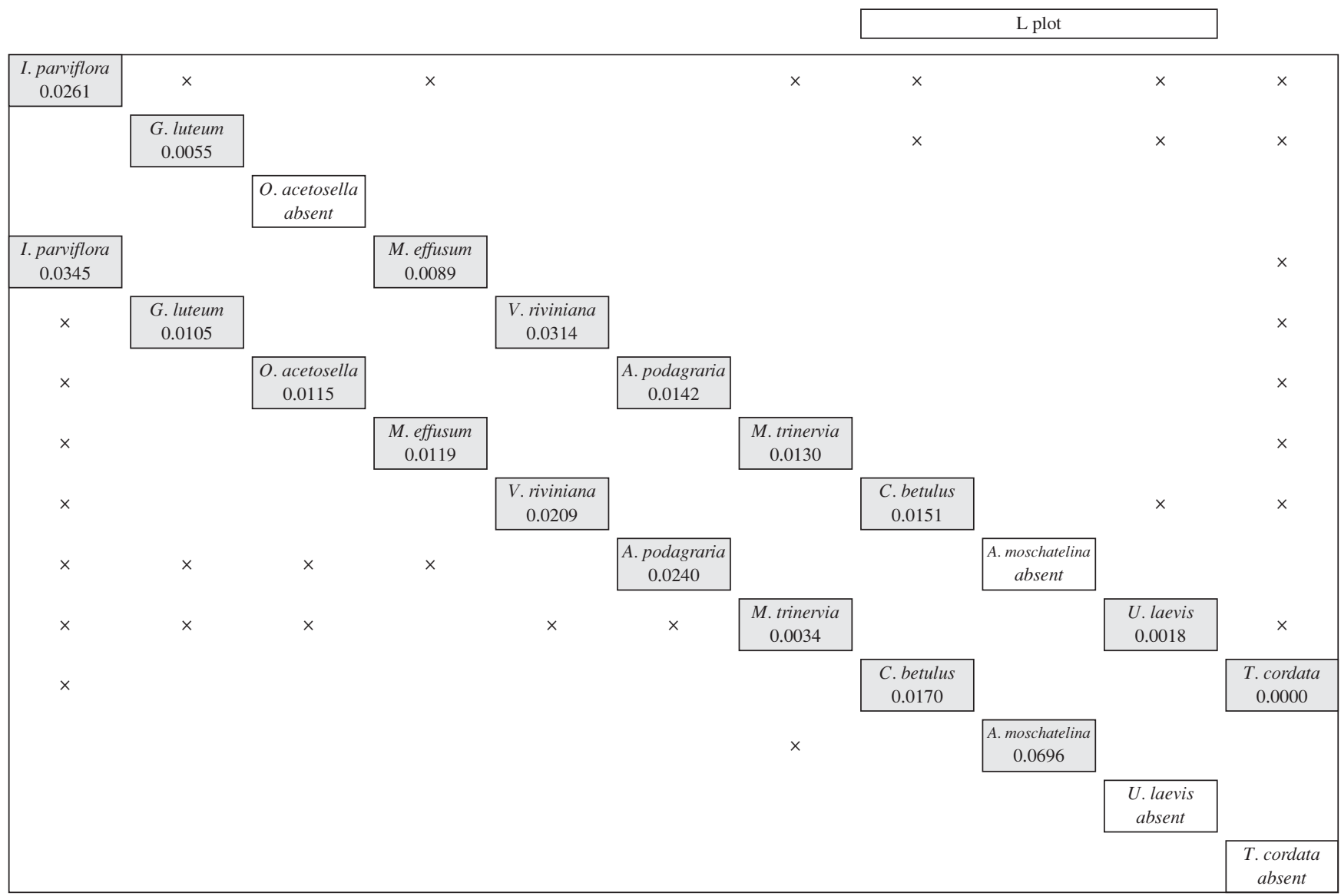


TABLE 3. Colonization $\left(N_{i}\right)$ of selected plant species of the herb layer of oak-hornbeam forest by Columella edentula under laboratory conditions. Below the plant name, the normalized number of $C$. edentula is given. $\times$ - significant $(\alpha=0.05)$ differences in colonization rate.

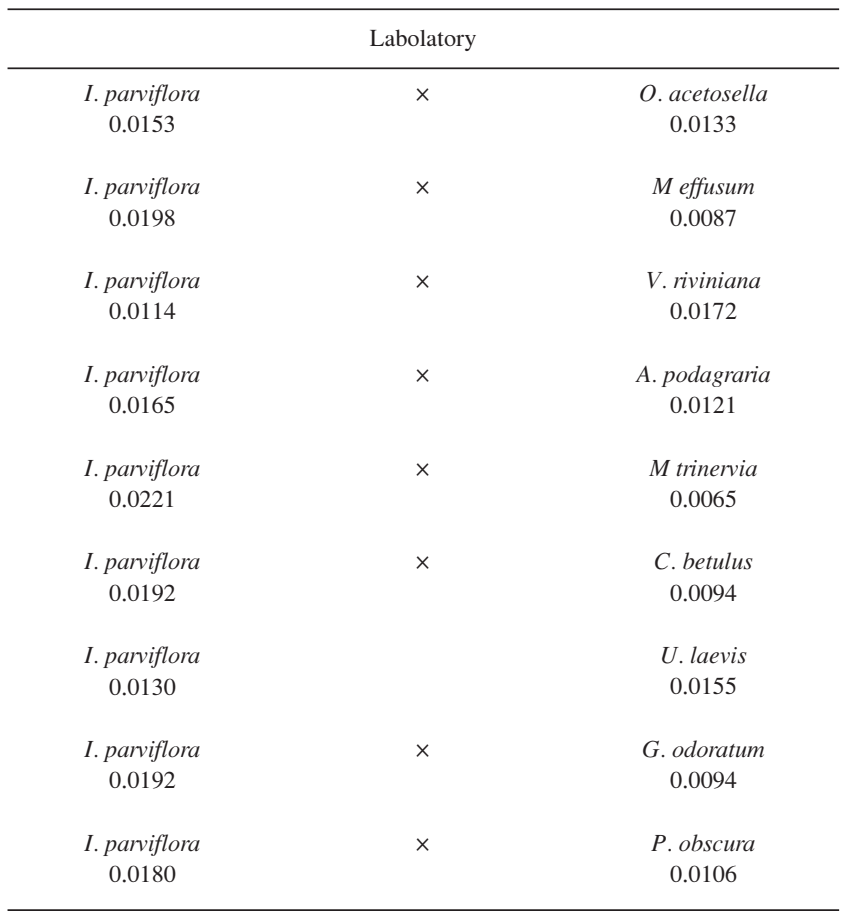

equal to $N_{0}$, while for all other species, $N$ values were lower than $N_{0}$ (Table 3).

The differences between normalized numbers of snails on I. parviflora and on other species were greater in the laboratory (H) than in the field (Fig. 2); on both plots in oak-hornbeam forest, similar differences between species were recorded. Relations between colonization of various plant species in the laboratory were more similar to results from plot K (for 5 species) than to results from plot L (for 3 species).

The laboratory experiment confirmed that under all conditions only I. parviflora was the most strongly colonized species. In all situations, Carpinus betulus, Milium effusum, Moehringia trinervia and Oxalis acetosella (absent from plot L), were less numerously colonized by $C$. edentula than I. parviflora.

Relatively small fluctuations in abundance of $C$. edentula were observed on I. parviflora (Fig. 3). The decreasing trend at the shaded site resulted only from natural death of these plants. The observations ceased in mid-August, so it is uncertain if later on the snail abundance on other plant species increased as a result. The experiment with removal of $C$. edentula from I. parviflora (plot $\mathrm{M}$ ) showed that snail abundance on I. parviflora was subject to smaller fluctuations than on other plants and stabilized already two days after removal (Fig. 4).

We did not observe any clear relationship between the rainfall and the variation in abundance on all plants and on I. parviflora (Fig. 3). Nevertheless, on cloudy and rainy days snails were more active. In the case of I. parviflora, on sunny days the snails were found mainly on the underside of leaves, on the midrib or lateral veins. Most individuals were then inactive. On rainy days, the snails were often active and more widely distributed over the plant (Fig. 5).

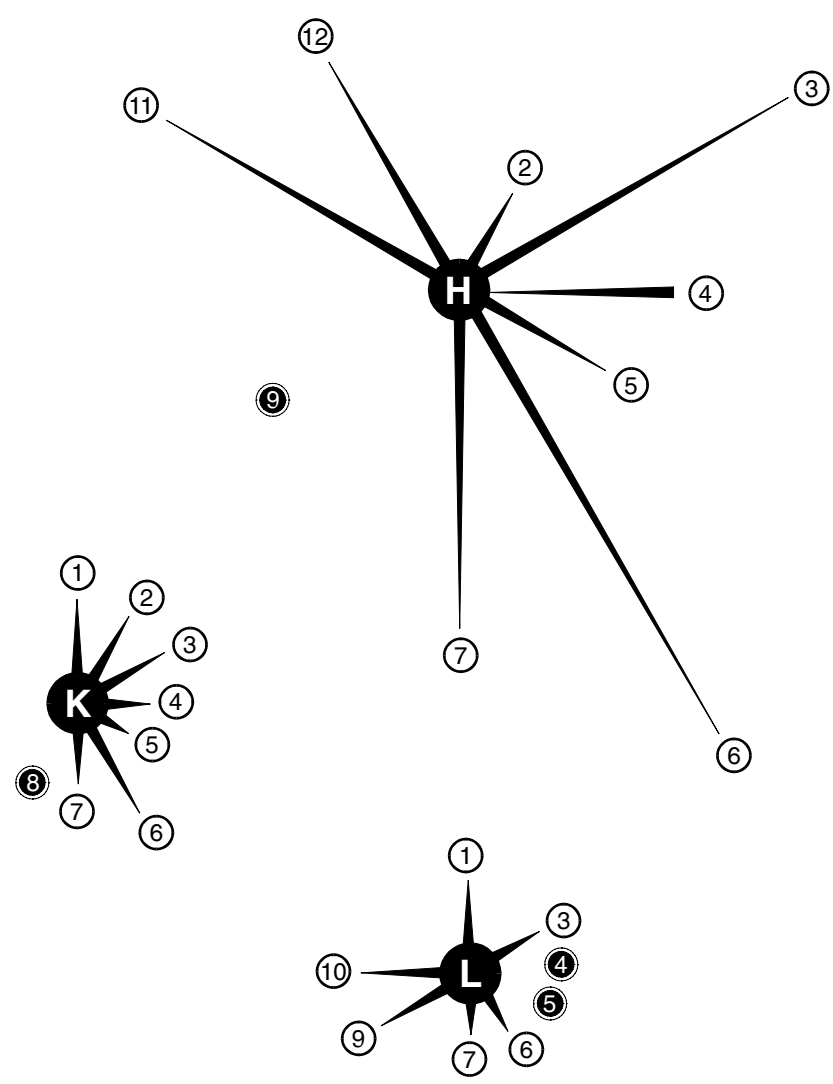

Fig. 2. Differences in the colonization $\left(N_{i}\right)$ of Impatiens parviflora and other species of the herb layer by Columella edentula on permanent plots $(\mathrm{K}, \mathrm{L})$ and in the laboratory $(\mathrm{H})$. Ray length reflects the magnitude of the difference between normalized number of snails on I. parviflora and the selected species; the wider part of the ray indicates the more colonized species; absence of a ray indicates that no significant difference was observed between the species and I. parviflora.

1 - Galeobdolon luteum Huds.; 2 - Oxalis acetosella L.; 3 - Milium effusum L.; 4 - Viola riviniana Rchb.; 5 - Aegopodium podagraria L.; 6 Moehringia trinervia (L.) Clairv.; 7 - Carpinus betulus L.; 8 - Adoxa moschatellina L.; 9 - Ulmus laevis Pall.; 10 - Tilia cordata Mill.; 11 - Galium odoratum (L.) Scop.; 12 - Pulmonaria obscura Dumort.

\section{Feeding observations}

On leaves of I. parviflora growing in the forests (in places with abundant occurrence of $C$. edentula) trades of feeding were observed which we attributed to the activity of C.edentula. This was confirmed during laboratory observations.

On I. parviflora, extensive patches eaten out by the snails covered nearly the whole leaf blades and were found also on stems. The injuries were always shallow, reaching to the mesophyll, so the leaves were never hollowed. Detailed observations of the injured leaves showed that the snails never fed near the midrib, primary lateral veins, and the leaf margins. Microscopic investigations revealed that those zones of mesophyll contain numerous idioblasts with calcium carbonate crystals (Fig. 6) which might prevent the snails from feeding.

\section{CONCLUSIONS}

The results show, that $C$. edentula favours $I$. parviflora over other plants as a place to rest on, in both field and laboratory conditions. The seasonal variation in abundance of 



Fig. 3. Seasonal variation in abundance of $\mathrm{Co}$ lumella edentula on Impatiens parviflora and other plants of the herb layer of oak-hornbeam forest. K - plot under the canopy; L - plot in the gap. Arrows indicate rainy days.

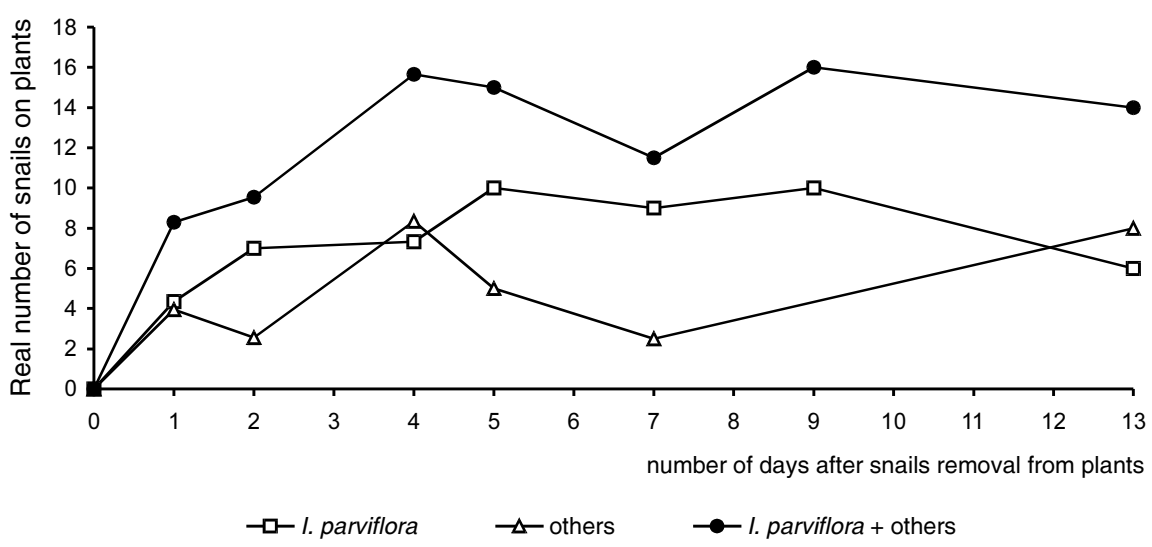

Fig. 4. Experiment on plot M: Rates of colonization of Impatiens parviflora and other plants of the herb layer of oak-hornbeam forest by Columella edentula.

C. edentula on I. parviflora was relatively low. After removal of $C$. edentula from plants, the number of snails on I. parviflora stabilized already two days after their removal, and was less variable than on other plants. For I. parviflora the numbers returned to levels seen in the non-removal plot.

The snails aggregated on the midrib and lateral veins in large numbers, so the protruding veins must be favourable sites for attachment. Additionally, the whole leaf blade ensures the highest, relatively stable humidity because the plant has hydathodes (Watson and Dallwitz 1992), and its stomata are located on the underside of the leaf. Apparently, the leaf blades could also play an important role in protection of the snails against predators, especially when the snails are not active.

Despite the fact that the small balsam has the protection in the form of calcium carbonate crystals, it is also eaten by the snail. Our data do not indicate, that the snail prefers this plant to other diet items.

Within its secondary range of distribution (Europe), I. parviflora interacts with $C$. edentula. Both species coexist also in the natural range of I. parviflora (Asia), so such an interaction may be expected there.

\section{ACKNOWLEDGEMENT}

This investigation was partially supported by the State Committee for Scientific research (KBN), Grant No. 3 P04G 05224.

\section{LITERATURE CITED}

BAIDASHNIKO V.A.A. 1992. Naziemnaja malakofauna Ukrainskogo Polecja. Soobszenie I. Vestnik zoologii No. 4: 13-19.

BRAUNE W., LEMAN A., TRAUBERT H. 1975. Practicum $\mathrm{z}$ anatomii roślin. PWN, Warszawa. (in Polish)

CAIN A.J., CURREY J.D. 1967. Studies on Cepaea. III. Ecogenetics of a population of Cepaea nemoralis subject to strong area effects. Physiological Transactions of the Royal Society of London, Series B, 253: 447-589. 

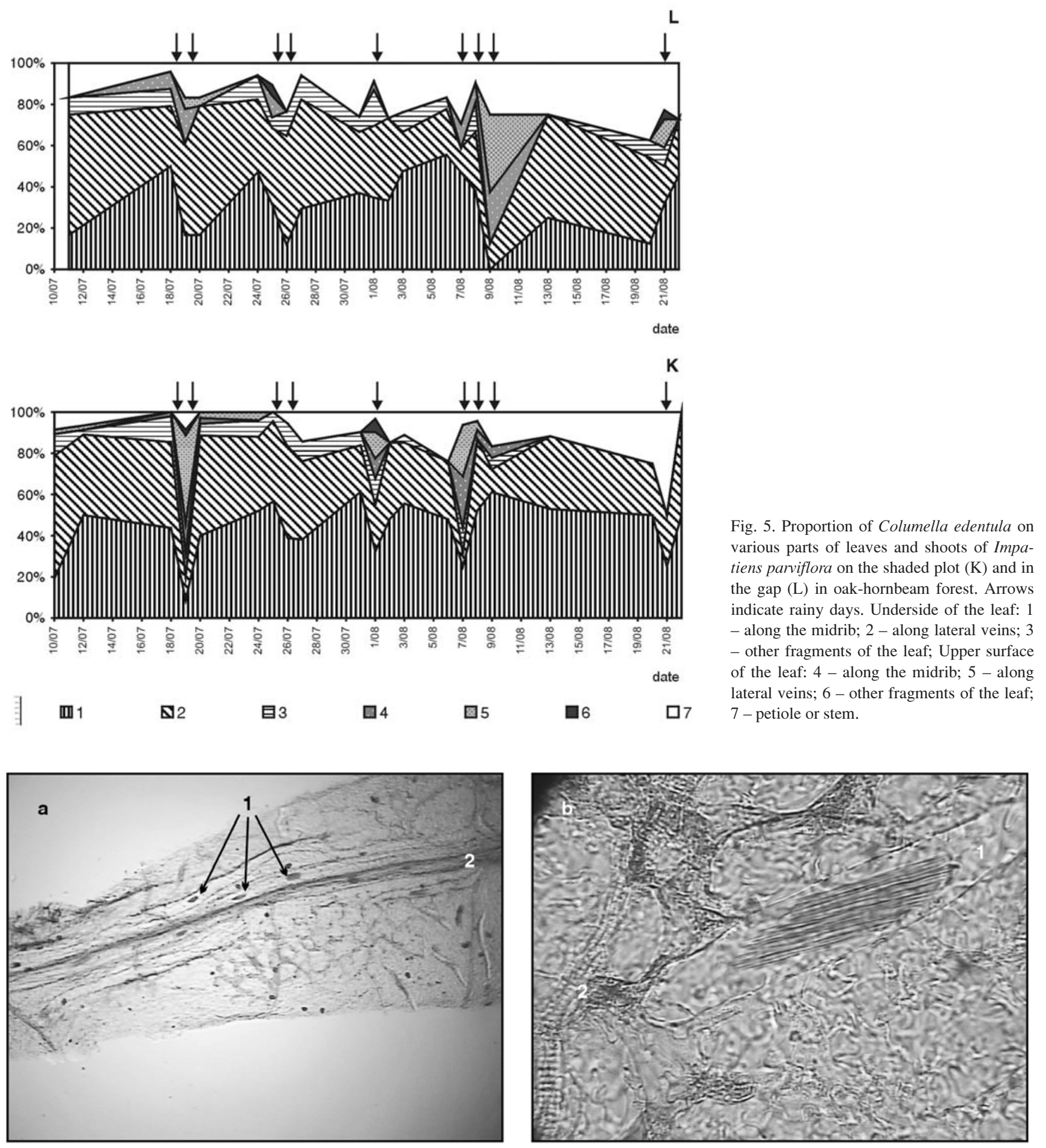

Fig. 6. Idioblast with crystals of calcium carbonate in the mesophyll of Impatiens parviflora. $1-\mathrm{CaCO}_{3}$ crystals; $2-$ midrib; a $-\times 50 ; \mathrm{b}-\times 200$.

CHATFIELD J. 1972. Observations on the ecology of Monacha cantiana (Montagu) and associated molluscan fauna. Proc. Malac. Soc. Lond., 40: 59-69.

CHATFIELD J. 1976. Studies on food and feeding in some European land molluscs. J. Conch., 29: 5-20.

ELIÁŠ P. 1989. Invasion of Impatiens parviflora an annual of Central-Asian origin into forest communities in Central Europe: Biological and ecological causes. In: Int. Symp. IAVS on Forests of the world: diversity and dynamics. Upsala Univ. 4s.

ELIÁŠ P. 2001. Invasion of an oak-hornbeam forest by aliens / exotic plant species: what is the mechanism of plant invasion? (Results of long term studies in SW Slovakia). $6^{\text {th }}$ International Conference Ecology and Management of Alien Plant Invasions. EMAPi Loughborough University. UK. 1s.
FALKNER G., BANK R.A., PROSCHWITZ T. 2001. Check-list of the non-marine Molluscan Species-group taxa of the States of Northern, Atlantic and Central Europe (Clecom I). Heldia 4 (1/2): 1-76, München.

FILUTOWICZ A., KUŻDOWICZ A. 1951. Mikrotechnika roślinna. PWRiL, Warszawa. (in Polish)

IGLESIAS J., CASTILLEJO J. 1999. Field observations on feeding of the land snail Helix aspersa Müller. J. Moll. Stud., 65: 411-423. The Malacological Society of London.

KRAWIECOWA A. 1951. Analiza geograficzna flory synantropijnej miasta Poznania. PTPN. Prace Komisji Biologicznej, 13 (1): 1-132, Poznań. (in Polish)

LOŽEK V. 1964. Quartärmollusken der Tschechoslowakei. Rozpr. Ustr. Ust. Geol. 31: 1-374, Praga. 
MEUSEL H., JAGER E., WEINERT E. 1978. Vergleichende chorologie der Zentraleuropischen Flora. Gustaw Fischer Verl. Jena. T1.

NICORTI M.E. 1980. Factors infolved in herbivore food preference. Journal of Experimental Marine Biology and Ecology. 42: 13-26.

ONDINA P., MATO S., HERMIDA J., OUTERIO A. 1998. Importance of soil exchangeable cations and aluminium content on land snail distribution. Appl. Soil Ecol., 9 (1-3): 229-232.

ORCZEWSKA A., CHMURA D. 2002. Impatiens parviflora DC. - inwazyjny neofit $\mathrm{w}$ zbiorowiskach leśnych Płaskowyżu Głubczyckiego i Wyżyny Śląskiej. In: German K., Balon J. (eds): Przemiany środowiska przyrodniczego Polski a jego funkcjonowanie. Ed. IG i GP UJ, Kraków. (in Polish)

PALLANT D. 1972. Food of the grey field slug, Agriolimax reticulatus (Müller), on grassland. J. Animal Ecol., 41: 761-769.

PILĀTE D. 2001. Fauna of terrestrial molluscs in coniferous forests of Lativia. Acta Biol. Univ. Daugavp. 1 (1): 34-37.

PISKORZ R. 2004. Biologia niecierpka drobnokwiatowego (Impatiens parviflora $D C$.) w fitocenozach Galio sylvatici-Carpinetum na terenie Wielkopolskiego Parku Narodowego. PhD thesis (unpublished).

POKRYSZKO M.B. 1990. The Vertiginidae of Poland (Gastropoda: Pulmonata: Pupilloidae) - a systematic monograph. Annal. Zoologic., 43 (8): 225-229.
SOLEM G.A. 1974. The shell makers. Introducing molluscs. John Wiley \& Sons, New York.

SPEISER B., ROWELL-RAHIER M. 1991. Effects of food aviability, nutritional value, and alkaloids on food choice in the generalist herbivore Arianta arbustorum (Gastropoda: Helicidae). Oikos, 62: 306-318.

STACHERSKA B. 1972. Impatientinum asiaticum Nevsky (Homoptera, Aphididae) - a species new to the Polish fauna. Bulletin Entomologique de Pologne, 42 (3): 12.

SHIKOV E.W. 1979. Wlijanie hozjajctwennoj dejatelnocti czeloweka na rasprostranienie nazemnych molljuskow. Ochrana prirody Werchnewodżja. Kalinin: Izd-wo KGU: 30-50.

TREPL L. 1984. Über Impatiens parviflora DC. als Agriophyt in Mitteleuropa. Diss. Bot., 73: 1-400.

WATSON L., DALLWITZ M.J. 1992. The Families of Flowering Plants. Balsaminaceae DC.: Descriptions, Illustrations and Identification, and Information Retrieval. Version $14 \times \mathrm{II}$ 2002; http://www.iodiversity.uno.edu/delta/

WÄREBORN I. 1970. Environmental factors influencing the distribution of land molluscs of oligotrophic area in southern Sweden. Oikos 21: 285-291.

WÄREBORN I. 1982. Environments and molluscs in a noncalcareous forest area in southern Sweden. Thesis Univ. Lund. 84 pp.

VAŠÁTKO J. 1973. Mekkýsi slozka geobiocenos jako ekoindikator. Stud. Geogr. 29: 183-191. 